\title{
Financial Literacy and Investment Decisions Among Traders in the Techiman Municipality
}

\author{
Evans Oteng \\ School of Business, Valley View University, P.O.Box AF 595, Accra, Ghana
}

\begin{abstract}
The goal of this study was to explore financial literacy and investment decisions among traders in the Techiman Municipality. A sample size of 150 respondents selected for the study. Convenience sampling technique was employed for the study. Questionnaire was employed for the study. Based on the findings it was established that traders lack knowledge in investment. Most of the respondents did not understand the concept of liquidity which describes the extent to which an asset can be promptly bought or sold in the market without affecting the asset's price. Additionally, the study indicated a strong positive relationship between financial literacy and investment decisions. It was realized that that $38.5 \%$ of the variations in the investment decisions are accounted for by the changes in the financial knowledge of the trader. The study recommended that more financial literacy programmes should be organized by the financial institution to create awareness. The government should also include financial literacy in the educational curriculum of the basic or elementary schools and higher learning institutions.
\end{abstract}

Keywords: Financial literacy, investment decisions, traders

DOI: $10.7176 /$ RJFA/10-6-07

Publication date:March $31^{\text {st }} 2019$

\section{Introduction}

Financial literacy has been recognised all around as a basic apparatus for development with issues identifying with budgeting, savings, investment and the administration of risks which are significant for the individuals, households and businesses in their developmental procedure. Financial literacy among the other categories of literacy has become the concern of most economics in the world. It has been established through research that financial literacy has a role to play in making sound investment decisions (Fazal, 2017).

In developed countries, there is a greater focus on educating an average family which involves helping it balance its budget, build assets, save for children's education and retirement planning. Although financial education includes individuals of all ages, education of young people in the area of finance is more significant the young age encounters more financial risks and more complicated financial products than their parents (Janor, Yakob, Hashim \& Aniza, 2016). Besides, traders are introduced to financial services at very early ages owing to cell phones, bank accounts, credit cards. From the study of Sabri (2016), traders' forms majority of business people in the world hence their knowledge on financial literacy should be prioritized. The situation is the same in the Techiman Municipality. The population and housing census of the municipality stated that traders constitute $46 \%$ of the population. Therefore, it is important that these traders are educated in finance as early as possible since their impact will lift the municipality higher in development.

According to Ajay and Sharma (2016), investment awareness and financial literacy have always been a very significant approach for informed financial decision-making process for every person. Besides, financial decision making has been widely acknowledged as one of the important factors that influence financial capability and financial wellbeing (Janor et al., 2016). Thus, distinguishing factors that are positively correlated with financial decisions is essential and is one of the central points for individual and national advancement. With all its importance, Fazal (2017), stated that it is one of the disciplines that has not received much attention. It was therefore not surprising that Owusu (2015) stated that the concept has been given little attention in Ghana and advocated for more studies in this area.

Generally, there is low level of financial literacy in Ghana (Barnara, 2015). A study in Ghana on adult, in 2009 about their financial literacy reveals a financial literacy level of $38 \%$ in the North, $44 \%$ in the middle belts and $51 \%$ in the Southern (Barnara, 2015). This was confirmed in a study by the National Financial Literacy Strategy in 2016, which stipulated that only $39 \%$ of Ghanaians are financially literate (Atakora, 2016). The report stated the need for financial literacy education since the lack of financial literacy had denied most Ghanaians of financial services. From the report, it is essential for the public to be educated on the financial opportunities that are there for the people to be able to access and invest in businesses, pay school fees and secure properties.

Recently in Ghana, some customers of microfinance organisation and fun clubs such as DKM Diamond microfinance, God is Love fun club, and the like lost virtually all their investment to these organisations (Owusu, 2015). Most of those victims were traders. Proper financial knowledge on investment and other financial related issues should have prevented those customers from being victims of such financial scams. Another issue that 
arose was that of 'money doubler' in the Techiman Municipality where people mostly traders lost a chunk of their capital forcing the Municipal Chief Executive to issue a statement on the need for traders to increase their knowledge on financial issues. Especially, in today's financial markets, stunningly developing products and services, increasing consumer debts, low financial literacy and changing socio-demographical conditions increase the importance of this education and necessitate the continuity of it hence the need for this study in the Techiman Municipality. It is against this background that the researchers seek to carry out a study on investigating financial literacy and investment decisions among traders within Techiman Municipality.

\subsection{LITERATURE REVIEW}

\subsection{Definition and Concept of Investment and Financial Literacy}

According to Jose, Rugimbana and Gatfield (2012), an investment decision revolves around the spending of capital on assets that yields maximum return for a company over a period. Thus, the decision concerns what commodity to buy so that the company gains the most value. To do this, there is a need for the company to find a balance between its short-term and long-term objectives. Within the short-term, a company needs money to settle its bills. However, keeping all of its cash means that the company is not investing in commodities that will assist it to grow. On the other end is a purely long-term view (Jappelli \& Padula, 2011). A company that invests all its money tend to maximise its long-term growth prospects. However, if that company does not hold enough cash, it cannot pay its bills and will go out of business soon. Companies thus need to find the right standard between long-term and short-term investment. The investment decision also includes what specific investments to embark on. Since no guarantee exists for the return of most investments, the finance department must determine an expected return.

There are varieties of ways one can go about investing. This includes engaging in stocks, bonds, mutual funds, real estate, gold, etc. The fact remains that no matter the method you choose, the prime aim is to put your capital to work so that it earns you an additional income or profit.

Financial literacy on the other hand according to Fannie Mae Foundation Report is the ability to read, critically analyse, manage, and effectively communicate personal financial conditions that influence material well-being (Jose et al., 2012). It includes the capability to appropriately discern financial choices, discuss money and financial issues with ease, plan appropriately for the future, and respond competently to life challenges that affect daily financial decisions, including financial events within the economy as a whole. Financial literacy presents to consumers the tools needed to maximise expected lifetime utility through the allocation of financial resources (Shaari, Hasan, Ramesh, \& Mior, 2013).

Financial literacy is the combination of investors' understanding of financial products and principles and their ability and dependability to consider financial risks and opportunities and make informed choices to take effective decisions aimed at improving their financial well-being (Ibrahim \& Alqaydi, 2013). Furthermore, financial literacy is the ability to comprehend how money works in our daily lives and how people manage to invest it and how they offer it to each other. Precisely, it means the set of ideas and skills that enable people to make rational decisions concerning their financial resources.

\subsection{Factors that influence traders' decisions on investment}

Research indicates that the level of investment knowledge may be positively correlated with ownership of risky assets. Weinstein (2014) found that, as investors become more knowledgeable, their willingness to take on risk increases, although experiencing a loss did not seem to visibly affect their judgement of their future investment success.

Conversely, less knowledgeable investors may avoid investing altogether. Arif (2015) found a causal link between low levels of financial literacy and stock market participation. They advocated for investor education programs (for private retirement plans) that target the least financially sophisticated segments of the population to address investors' reluctance to invest in the stock market.

Almenberg and Widmark (2011) cited in Weinstein (2014) conducted a study in Sweden and found that numeracy and financial literacy were strongly correlated with participation in both stock and housing markets. These findings were in line with prior research (Hussein \& Anood, 2010) and supported the view that nonparticipation is a standard response to shortfalls in numeracy and financial literacy.

Musundi (2014) indicated that past decisions impact the decisions individuals make in the future. It is a fact that when something positive results from a decision, individuals are more probable to decide in a related way, given a similar position. Also, individuals tend to bypass reiterating previous errors. This is true to the extent that expected decisions made based on previous experiences are not significantly the best decisions. In financial decisions, highly successful individuals do not make investment decisions based on former sunk outcomes, rather by examining choices without past experiences; this approach conflicts with what one may expect.

\subsubsection{Gender}

Globally, evidence suggests that men, on average, hold more high-risk assets than women (OECD, 2013). This is 
sometimes attributed to women being more risk-averse than men. However, a recent study sought to test two alternative explanations: differences in asset allocation between men and women may also occur if investors have different expectations about future returns and different perceptions about the riskiness of financial assets (Jacobsen, Lee, Marquering \& Zhang, 2014). The findings of the study suggested that the difference between men and women in holding higher-risk assets largely stemmed from women being less optimistic about future market performance and more likely to predict a higher level of market risk than men. Jacobsen et al. (2014) noted that men's optimism might be linked to having higher confidence levels and a greater perceived ability to influence outcomes. They also found that gender difference in optimism is not limited to the stock market, but extends to other aspects of the economy and private life.

A survey of investors in Canada found that optimism is a personal trait that often leads to mistakes due to overconfidence (Weinstein, 2014). In line with their higher risk appetite, men were more likely to experience a major investment loss than women. This gender difference may also explain statistics showing that three out of four pre-retirement investors who have been the target of investment fraud are men.

\subsubsection{Age}

A report by Stanford University (2014), supported by a grant from the US FINRA Investor Education Foundation, found that older people tend to make more investment mistakes when choosing higher-risk assets. Investment mistakes were associated with the anticipation of rewards, suggesting that older adults might make overly optimistic predictions about the potential earnings of risky stocks. However, it was further found that these mistakes could be reduced by providing "decision aids" for risky investments. Interestingly, the format of these decision aids is important such that older adults made better choices when provided with these simplified estimates of expected value than when provided with a detailed record of each asset's prior returns over time.

Research has shown that age, socioeconomic status (SES), and cognitive abilities impact the decision-making process (Mahfudh, 2014). Finucane et al. (2005) cited in Amponsah (2015) discovered a meaningful difference in decision making across age; that is, as cognitive functions decline, the concept of decision-making performance may decline as well. Also, older people may be more overconfident concerning their capacity to make decisions, which inhibits their ability to apply policies (Arif, 2015). Finally, of age, there is evidence to support the notion that older adults prefer fewer choices than younger adults.

\subsubsection{Cognitive Biases}

Cognitive biases are the thinking patterns based on observations and generalisations that result in memory errors, inaccurate judgments, and faulty logic (Wagner \& Wagner, 2015). Cognitive biases involve but are not limited to biases in belief, the over-dependence on previous ideas in arriving at decisions; omission bias and confirmation bias.

During decision making, cognitive biases impact people by causing them to rely over upon expected observations and past ideas, while dismissing information that is perceived as unlikely, without looking at the bigger picture. While this impacts may lead to poor decision-making, the cognitive biases enable people to make effective decisions with the assistance of heuristics (Bayrakdaroğlu, 2015).

\subsubsection{Product complexity}

The United States Securities and Exchange Commission in 2012 commissioned a study to assess investors' understanding of target date retirement funds. These funds, hold a mix of stocks, bonds, and other investments. Over time, the mix gradually shifts according to the fund's investment strategy and its timeline. The study showed that some respondents did not fully understand the investment risks of target date retirement funds. For example, many survey respondents had misconceptions about the point at which the asset allocation of a target date fund stops changing. Also, only $36 \%$ of respondents correctly indicated that a target date fund does not provide guaranteed income in retirement (Wagner \& Wagner, 2015).

The UK FCA (2015) cited in Bayrakdaroğlu (2015), has also reviewed to investigate how well retail investors understand and value structured deposits - a type of complex product. The review sought to assess whether there are systematic biases in investors' evaluation of the expected performance of these products and whether giving targeted information improves this evaluation. The key findings included that:

- consumers had a good understanding of basic product features, but struggled with the details;

- consumers struggled to assess potential product outcomes or performance, and significantly overestimated expected returns on structured deposits;

Overall, the research findings reinforced UK FCA's belief in the importance of designing structured goods that fairly match for the financial sophistication of the particular target market. It also highlighted areas in which further research could be undertaken to understand better which combination of product features and behavioural biases drive investors to have very high expectations of product returns and prevent their ability to evaluate and compare structured products.

\subsection{Financial Literacy and investment decision}

Availability of financial information has been identified as one of the key variables that influence investor 
investment behaviour towards the investment option to adopt. Financial information includes accounting reports, general information about price movements, firm reputation, status of a firm in the investment market, past performance of the firm stock, as well as the expected performance of the firm (Chong and Lal, 2011). Financial information influences an investor when making a decision towards investing in stocks as an individual tend to evaluate previous underlying movements of the various key indicators relating to a particular investment portfolio. Jariwala and Sharma (2013) posited that financial information has a significant and positive effect on expected corporate returns.

According to Easley, Hrickjaer and O'Hara (2010), when taking the decision adopt a particular investment type, investors normally starts with the assessment of firms financial positions based on measures including equity or earning per share. Usually, their perceptions of such evaluations affect how they justify their investment decisions within a given firm. Chong and Lal (2011) stated that when adopting a particular investment decision, individuals seek information on firm's performance as well as the investment behaviour of other investors in the market. The timing and delivery of such information concerning the market had a substantial influence on how investors make their decisions (Karan Gupta \& Negi, 2014).

Chrisann (2014) also realised that Annual Reports and interviews with officials of companies mostly determined the sources of information in assessing a company's value thereby informing the equity adoption process. Before an investor adopts any investment decision, the investor evaluates the financial statements of various firms to aid his decision for a financial decision. Due to this, financial analysts become useful in gathering and analysing as well as giving the interpretation of the accounting results; which is subsequently circulated to potential investors to aid their investment decisions. Kiplangat, Bitok, Tenai and Rono, (2010) examined the determinants of investor confidence in Kenya of which the findings of their study indicated daily price movements within the NSE. This movement significantly related to investor sentiment, which implies that investors are guided by the information available to make a sound decision towards invest in shares.

Bhushan (2014) examined the nature of indicators that had a greater influence on investor's needs and those that motivate an investor to invest in equity shares. The study evaluated these factors using data from firms trading on the Jakarta Stock Exchange. The outcome of the results indicated that investors in emerging markets usually require certain metrics as tools to properly analyse and predict appropriately the value of shares. The study stated that the metric gives the means to verify the interrelationships among external risks, and the value of shares that influence the quality of investment decisions.

Several studies have indicated that financial illiteracy is widespread and that several individuals lack financial knowledge; even the most fundamental economic principles (Musundi, 2014). The relationship which exists between financial literacy and investment decision-making is less clear. Rooij, Lusardi and Alessie (2011) indicated that individuals who have lower financial literacy are prone to invest. Mahfudh (2014) find that individual's financial literacy is a good indicator for the diversification of his or her portfolio. Using investor's wealth and profession as a proxy for financial literacy, Narula (2015) find empirical evidence which indicated that more literate investors are less prone to the disposition effect.

The results of Müller and Weber (2010) indicated a positive relationship between financial literacy and investments in low-cost funds. However, the study revealed that even the most complicated investor selects actively managed funds instead of less expensive exchange-traded funds. They noted that even finance professors who are presumably thought to have high financial literacy do not utilise their financial knowledge when building their portfolio. The findings of Doran, Peterson, and Wright (2010) supported this claim. Their study found out that professors' perception of market efficiency and their important optimal investment strategy were unrelated to their behaviour. The study argued that the professors' investment decisions were driven by behavioural factors comparable to illiterate investors despite their high financial literacy level. Hibbert, Lawrence, and Prakash (2012) documented that most finance professors do not even participate in the investment market at all. Additionally, a lot of studies had documented a weak impact of financial literacy on the quality of investment decisions (Müller \& Weber, 2010; von Gaudecker, 2011).

Bhushan (2013) examined the awareness level and investment behaviour of salaried individuals towards financial products. The researcher concluded that respondents were quite aware of traditional and safe financial products whereas the awareness level of new age financial products among the population was low. The majority of the respondents park their money in traditional and safe investment avenues so people must be made more aware of new investment opportunities available in the market. This research dealt with salaried workers, and hence the outcome might be different from those traders who are considered in this study.

Ibrahim and Alqaydi (2013) examined the financial literacy among individuals residing in the United Arab Emirates (UAE). The results indicated that the average level of financial literacy in UAE was statistically significantly below the average level reported in the literature. The study registered no significant differences between the mean score of males and females. The results also indicated that individuals with strong financial attitude tend to borrow less from credit cards. UAE nationals were more likely to borrow from banks than using credit cards or borrowing from friends or family members. The research, however, took place in non-African 
settings and hence might be influenced by the environment.

Vasantbhai, Sakaria and Sima (2013) in their study focused on identifying and evaluating the financial literacy among retired persons of Rajkot city. With F - Test and Sandler - 'A' at 5\% level, the researcher concluded that $88 \%$ of respondents were knowledgeable about how to invest and where to invest and $12 \%$ of respondents were not aware of the same. The age group and savings were found to affect the issues related to financial literacy. Research also found that market information and skills were necessary for an investment decision. The geographical scope of the study involved retired workers whose conditions might be different from traders in this study.

Thilakam (2012) in his paper, tried to assess the financial literacy of rural masses in India. The researcher has analysed the socio-economic conditions of the rural masses and the correlation of the income, expenditure and savings pattern, the savings modes and investment avenues and its awareness among the rural masses, the various factors that determine the current savings/investment patterns of the rural masses. The researcher concluded that today's financial world is highly complex when compared with that of a generation ago and in comparison to urban people the rural people have a low level of awareness on finance matter. The research, however, took place in non-African settings and hence geographical difference could cause a variation in the outcome of the results.

Kevin (2014) assessed the financial literacy of real estate investors who invested in the real estate industry. Also, it examined the link between financial literacy and the impact of the factors that affect the investment decision process. From the results, the financial literacy level was found to have a significant effect on investors' investment decision-making process. The study outlined that to achieve optimal outcomes in this complex decision-making environment; there is a need for decision-makers to have adequate financial ideas and skills. The research recommended for further study on the influence of inflation rates on investment decision-making and ways to resolve any sudden losses due to inflation.

\section{Method}

This study employed a descriptive survey design.

\subsection{Population and Sampling Techniques}

The target population for the study consist of traders who operate within the Techiman Municipal stores in the Techiman Market.

The sample for the study was one hundred and fifty (150) traders. Convenience sampling technique was employed to select the respondents. The convenience sampling was adopted to ensure that traders selected for the study were those who exhibit an interest in participating in the study and were ready to answer the questionnaire.

\subsection{Type of Data}

Both quantitative and qualitative data were collected for this study.

\subsubsection{Research Instrument for Data Collection}

The research instrument for this research were questionnaires. To guarantee that the language of the questionnaire was clear in soliciting for correct information, the researcher discussed the final questions with a number of experts in the field who gave suggestions to enhance the outcome of the results. This was an attempt to find out whether the questionnaire drawn was adequately prepared, clearly understandable and would measure the set objectives of the research appropriately. In addition, the researcher supplied six respondents with the draft copy of the questionnaire. Respondents after that were given time to complete and return the questionnaire to the researchers. These views were collated and studied closely by the researcher. Minor lapses were corrected before the final questionnaire was administered.

The questionnaire was coded and tabulated for analysis.

\subsection{Method of Data Analysis}

The study used the percentages and mean analysis to determine the traders level of investment knowledge and also determine the determinants of decisions of traders. Means and the standard deviation was used to find the relationship between financial literacy and investment decisions of the traders.

\section{Results}

\subsection{Research Objective one: Traders level of knowledge on investment in the Techiman Municipality}

The objective test approach was applied to test the respondents" knowledge and understanding of financial terms and their ability to apply numerical skills in situations related to finance. Objective test questions were asked concerning liquidity, inflation and interest rate, risk and return. On liquidity, items are given for respondents to indicate or tick which one of them can be easily turned into cash. The study had $75(50 \%)$ of the respondents 
indicated 'Not sure'; 10 (6.7\%) indicated cash crops; $40(26.7 \%)$ for items in shop; $5(3.3 \%)$ for money in fixed accounts and $20(13.3 \%)$ for money in current accounts.

On the issue of inflation and interest rate, the researcher wanted to know from respondents what the effect on purchasing will be like after a year if interest rate on savings accounts is $10 \%$ per year and inflation rate is $12 \%$ per year. The following findings were gathered; $121(80.7 \%)$ are not sure what the effect will be like; $3(2 \%)$ believe one can buy the same with the money in the account; $6(4 \%)$ believe one can buy more with the money in the account and $20(13.3 \%)$ believe one can buy less with the money in the account.

On risk and return, 67 (44.7\%) of the respondents answer that investment with high return is likely to have high risk. $15(10 \%)$ believe there will be low risk; $10(6.7 \%)$ believe there will be no risk and $60(40 \%)$ are not sure.

\subsection{Research Objective Two: What factors determine traders' level of investment in the Municipality?}

The questionnaires were answered based on a five-point rating scale. The researcher adopted the Simple Percentage Method and the Mean Analysis to analyse this part of the questionnaire. The Simple Percentage Method is a method used to summarise the percentage of respondents who agreed or disagreed to a particular item and the Mean Values indicate the extent of the disagreement or disagreement of the item. To analyse the results under any dimension, all questions covering that dimension were aggregated. The mean value of 3 and above indicate that respondents agreed that a particular factor is influences traders decision to invest. The findings are presented in Table 1 below.

From the Table, the items were grouped under personal financial needs, advocate information and accounting information.

On personal financial needs, factors considered included minimisation of risk, expected losses in other local investment, ease of obtaining loans, expected dividends and diversification purpose. Respondents agreed that all these factors affect their investment decisions except the expected losses in other local investors. For the individual factors, the study $66.7 \%(42.7 \%$ who agreed and $24 \%$ who strongly agreed $)$ of the respondents concluding that minimization of risk is among one of the factors that influence their decision making in investment, $8.7 \%$ thought that risk is part of business hence their decision to invest is not influenced by it. However, $24.7 \%$ of the respondents could not conclude on the fact that minimising risk plays a role in their decision to invest. The result is supported by the 3.73 mean value registered by the statement.

With expectation of losses in other local investment affecting traders decision to invest, $60 \%(17.3 \%$ who strongly disagree and $42.7 \%$ who disagreed) of the respondents stated their disagreement while the remaining $40 \%$ indicated that expected losses in other local investment influences their decision to invest in a particular area. This is supported by the mean of 2.86 indicated by the study.

On the assertion that traders invest so that they can easily obtain loans, $27.4 \%$ disagreed, $47.3 \%$ agreed while $25.3 \%$ could not make a conclusion. This assertion achieved a mean value of 3.25 .

Concerning the fact that expectation of dividends drives their investment decision-making process, $27.3 \%$ did not agree. As much as $54.6 \%$ of the respondents agreed that expected dividends from investment affect their decision to invest. This is indicated from the mean value of 3.33 achieved from the study.

Additionally, the adoption of a particular decision due to reasons of diversification had a mean value of 3.40. The study had $50.6 \%$ who agreed to this assertion.

On advocacy information, the only factor rejected by the respondents as influencing their investment decisions was family member opinion. All other factors; financial advisors and analysts' recommendation, opinion of the business partners and recommendation from friends were affirmed by respondents to influence their investment decisions.

The study had $49.3 \%$ agreed that they listen to financial advisors and analyst recommendations whenever they want to invest. The mean value of 3.37 achieved indicated that respondents agreed to this assertion.

On the opinions of the firm's partners influencing the decision to invest, it was indicated from the results that the respondents answered in the affirmative. A mean value of 3.21 was achieved indicating the agreement of the respondents that the opinions of the business partners influence their decision to invest. Respondents also agreed that recommendations from friends play a crucial role in their decisions on the investment to adopt. As much as $66.7 \%$ agreed that they consulted friends who either recommended or rejected a particular decision to invest before they adopted it. A mean value of 3.73 affirmed this assertion.

However, the study indicates that majority of traders do not factor in their family members' opinion when taking investment decisions. This assertion registered a mean value of 2.86 which fell below the standard mean of 3 . As much as $60 \%$ of the respondents indicated that they are not influenced by decisions from family members when taking a particular decision to invest. On the accounting information, respondents agreed that conditions of financial information, past performance of the firm as well as expected performance of the firm impact their decision to invest in the firm.

Above all, $50.6 \%$ of the respondents indicated that they consider the condition of financial statement of the 
firm before making decision to invest in that firm as against 32\% who disagreed. For those who agreed that past performance of the firm affects their investment decision, $49.3 \%$ agreed while $33.3 \%$ disagreed. Also, $49.3 \%$ agreed that expected performance of the firm influence their investment decision with $32 \%$ disagreeing.

\subsection{The relationship between financial literacy and investment decisions in the Municipality}

To examine the relationship between financial literacy and investment decisions, knowledge of financial literacy served as the dependent variable while reasons for investment (factors affecting investment decisions) served as the independent variable. Descriptive table for the results is indicated in Table 6 . The description of the variables used are shown in Table 2.

The mean establishes the weight of each item to the model. From this model, a higher mean value is an indication that respondents confirmed the existence and impact of that variable. The standard deviation gives the dispersion of the variable from the mean. A smaller value of the standard deviation implies that the variables are clustered around the mean and gives the validity of the mean to be used in the analysis. It is also a measure of the absence of outliers in the data. The mean value for financial literacy is 2.99 with a standard deviation of 1.298 , and that of the investment decision is 3.31 with a standard deviation of 1.105 . The model summary is shown in table 3

R-squared defines the coefficient of determination which describes the variation in the independent variables due to change in the independent variables. The R-squared value of .385 in Table 3 shows that there was a variation of $38.5 \%$ on investment decision due to changes in financial literacy by traders at $5 \%$ standard error. What this means is that $38.5 \%$ of the variations in the investment decisions are accounted for by the changes in the financial knowledge of the trader, and the remaining $61.5 \%$ are accounted by other factors contained in the standard error.

$\mathrm{R}$ depicts the relationship coefficient which displays the association between the research variables. From these findings, there was a strong positive relationship between the study variables as indicated by 0.620 . This means that the higher one's knowledge in financial literacy, the higher he invests. The ANOVA statistic is shown in Table 4 below:

The $\mathrm{p}$ value helps in determining if your condition means were relatively the same or if they were significantly different from one another. Put differently, this value will help you determine if the investment decisions adopted by the traders are affected by their knowledge in finance.

From the ANOVA statistics shown, the processed data had a significance level of 0.000 which shows that the data is ideal for making any conclusion on the investment decisions as the value of significance (p-value) is less than 5\%. The F critical at 5\% level of significance was 2.42. Since F calculated (15.143) is greater than the F critical (2.72), this shows that the overall model was significant and that financial literacy significantly predicts investment decisions.

\subsection{Discussion of Findings}

\section{Traders level of knowledge on investment in the Techiman Municipality}

The study indicate that respondent's knowledge and understanding of liquidity, inflation and interest rate is low since most of them indicated they were not sure. The results indicate that most of the traders lack knowledge in investment. This result agrees with many studies such as Lusardi and Mitchell (2007), Hilgert, Hogarth and Beverly (2003) and Rooij, Lusardi and Alessie (2011). According to Müller and Weber (2010) several individuals lack investment knowledge; even the most fundamental economic principles. They noted that even finance professors who are presumably thought to have high investment literacy do not utilise their investment knowledge when building their portfolio. The findings also agree with that of Doran, Peterson, and Wright (2010). Their study found out that professors' perception about market efficiency and their consequential optimal investment strategy were unrelated to their behaviour. The researchers argued that the professors' investment decisions were driven by behavioural factors comparable to illiterate investors despite their high financial literacy level.

\section{Factors that determine investment decisions of traders in the Municipality}

The study indicated that on personal financial needs, factors considered included minimisation of risk, expected losses in other local investment, ease of obtaining loans, expected dividends, diversification purpose and family member opinion. All other factors; financial advisors and analysts' recommendation, opinion of the business partners and recommendation from friends were affirmed by respondents to influence their investment decisions. Other factors were past performance of the firm as well as expected performance of the firm impact their decision to invest in the firm. This result is in consonance with that of Chong and Lal (2011) who stated that the availability of financial information has been identified as one of the key variables that influence investor investment behaviour towards the investment option to adopt. Respondents, however, rated the condition of financial information on the firm as a higher factor they consider followed by past performance of the firm before looking at the expected performance of the firm. This is why Merika (2008) posited that financial 
information has a significant and positive effect on expected corporate returns. According to Easley et al., (2010), when taking the decision to adopt a particular investment type, investors normally starts with the assessment of firms financial positions based on measures including equity or earning per share. Usually, their perceptions of such evaluations affect how they justify their investment decisions within a given firm. Chong and Lal (2011) stated that when adopting a particular investment decision, individuals seek information on firm's performance as well as the investment behaviour of other investors in the market. The timing and delivery of such information concerning the market had a substantial influence on how investors make their decisions (Hughes, 2008).

\section{The relationship between financial literacy and investment decisions of traders}

Objective three sought to investigate the relationship between financial literacy and investment decisions of traders. The study indicated a strongly positive relationship between financial literacy and investment decisions. This means that, the higher one's knowledge in financial literacy, the higher he invests. It was realised that that $38.5 \%$ of the variations in the investment decisions are accounted for by the changes in the financial knowledge of the trader. The results conform with earlier findings from Thilakam (2012), Agarwalla, Barua, Jacob and Varma (2012) and Vasantbhai, Sakaria and Sima (2013). All the studies found a positive relationship between financial literacy and investment decisions

\section{Conclusion}

Conclusively, the study reveals traders had little knowledge in investment. Most of the traders did not understand the concept of liquidity, the implication of interest rate and inflation on their business and the implication of their decision to adopt a high-risk business or low-risk business on returns. However, there is a significant correlation between financial literacy and investment decisions indicating that the ability of one to take sound investment decisions and invest more is dependent on the level of financial literacy.

\subsection{Recommendations}

The study revealed that respondents' knowledge and understanding of liquidity, inflation and interest rate is low since most of them indicated they were not sure. The results indicate that most of the traders' lack knowledge in investment. It is therefore recommended that more financial literacy programmes should be organized by the financial institution to create awareness. The government should also include financial literacy in the educational curriculum of the basic or elementary schools and higher learning institutions.

It was also revealed that personal financial needs, factors considered included minimization of risk, expected losses in other local investment, ease of obtaining loans, expected dividends, diversification purpose and family member opinion are factors that determine investment decisions. All other factors; financial advisors and analysts' recommendation, opinion of the business partners and recommendation from friends were affirmed by respondents to influence their investment decisions. It is therefore recommended that these factors be taken into consideration when planning financial literacy programmes by the financial institutions during the awareness creation times.

Last but not least, the study indicated that a positive relationship between financial literacy and investment decisions. This means that the higher one's knowledge in financial literacy, the higher he invests. Hence, it is recommended that traders take measures to educate themselves on financial issues since this will influence their decisions on investment.

\section{Acknowledgments}

I wish to recognize Valley View University for its financial support for this particular study. In addition 1 wish to also, acknowledge Emmanuel Addai who assisted in conducting the study.

\section{References}

Agarwalla S. K., Barua S., Jacob J. \& Varma J. R. (2012). A survey of financial literacy among students, young employees and the retired in India, Indian Institute of Management Ahmedabad.

Ajay, S. and Sharma, R. (2016). Financial literacy \& its impact on investment behaviour for effective financial planning, 6(8), 50 63.

Almenberg, J., and A. Dreber. 2011. Gender, financial literacy and stock market participation. Working Paper, Stockholm School of Economics.

Amponsah, B. (2015). Assessing the effect of financial literacy on saving behaviour: A case study of small scale miners in Manso Atwere in Amansie West District.

Arif, K. (2015). Financial literacy and other factors influencing individuals' investment decision : Evidence from a developing economy (Pakistan). Journal of Poverty, Investment and Development, 12(September), 74-85.

Atakora, A. (2016). Measuring the Effectiveness of Financial Literacy Programs in Ghana. International Journal of Management and Business Research, 3(2), 135-148.

Barbara, (2015). Assessing the effect of financial literacy on saving behaviour: a case study of small scale miners 
in Manso Atwere in Amansie West District. A thesis submitted for master of business administration, Kwame Nkrumah University of Science and Technology, Kumasi, Ghana.

Bayrakdaroğlu, A. (2015). Impact of financial education on financial literacy levels and diversity of investment choices. Academic Research on Global Business, Economics, Finance and Banking, 25, 3-5.

Bhushan, P. (2014). Relationship between financial literacy and investment behavior of salaried individuals. Journal of Business Management \& Social Sciences Research, 3(5), 2319-5614.

Chong, T.P. \& Lal, M.M. (2011). An Empirical Evidence of Factors in Equity Selection Process in Malaysia. African Journal of Business Management, 5 (15), 6221-6232.

Chrisann, P. (2014). Financial literacy and superannuation investment decision-making in a choice environment : An exploratory study.

Doran,J.S., Peterson,D.R.\& Wright, C. (2010).Confidence, opinions of market efficiency, and investment behavior of finance professors. Journal of Financial Markets13 (1), 174-195

Easley, D., Hrickjaer, S. \& O'Hara, M. (2010). Factoring information into returns. Journal of Finance, 45, 293 309.

Fazal, H. (2017). Effect of Emotional Intelligence on Investment Decision Making With a Moderating Role of Financial Literacy. China-USA Business Review, 16(2), 53-62.

Finucane, M. L., Mertz, C. K., Slovic, P., Schmidt, E. S. (2005). Task complexity and older adults' decisionmaking competence. Psychology and Aging, 20, 71-84.

Hibbert, A.M, Lawrence E.R. \& Prakash, A.J. (2012). Do Finance Professors Invest Like Everyone Else? Financial Analysts Journal 68(5), 95-105.

Hilgert, M.A, Hogarth, J.M, \& Beverly, S.G. (2003). Household Financial Management: The connection between knowledge and behavior. Fed. Res. Bull. 89, 309-322.

Hughes, A. (2008). Head Space: Understanding Investor Psychology can help you steer your Clients Toward Good Investing Decisions in Bad Markets. Bank Investment Consultant, 16 (1), 28 - 35.

Hussein A. Hassan Al-Tamimi and Al Anood Bin Kalli. (2009). Financial Literacy and Investment Decisions of UAE Investors. The Journal of Risk Finance, 10 (5), 500-516.

Ibrahim, M. L., Alqaydi, F. R. (2013). Financial literacy, personal financial attitude, and forms of personal debt among residents of the UAE. International Journal of Economic and Finance, 5(7), 126-138.

Jacobsen, B, Lee, J, Marquering, W \& Zhang, CY 2014, 'Gender Differences in Optimism and Asset Allocation' Journal of Economic Behavior \& Organization, 107, 630-651.

Janor, H., Yakob, R., Hashim, N. A., \& Aniza, C. W. C. (2016). Financial literacy and investment decisions in Malaysia and United Kingdom: A comparative analysis. Malaysian Journal of Society and Space, 12(2), 106-118.

Jappelli, T., \& Padula, M. (2011). Investment in Financial Literacy and Savings Decisions. Journal of Banking and Finance, 37(8), 2779-2792.

Jariwala, H. V, \& Sharma, M. S. (2013). To study the level of financial literacy and its impact on investment decision.

Jose, S., Rugimbana, R., \& Gatfield, T. (2012). Consumer Responses to CSR Driven Microfinance Strategy of Banks-An Empirical Investigation Based on India. International Journal of Business and Management, $7(21), 1-15$.

Karan Gupta, \& Negi, V. (2014). Financial literacy of himachal pradesh. A case study of Shimla. IMPACT: International Journal of Research in Business Management (IMPACT: IJRBM), 2(9), 1-14.

Kevin M. M. (2014). The effects of financial literacy on personal investment decisions in real estate in Nairobi County. A research project for masters, University of Nairobi

Kiplangat, A.P., Bitok, J.L., Tenai, J.\& Rono, L. (2010). Determinants of Investor Confidence for Firms Listed In Nairobi Stock Exchange. Eldoret: Unpublished Moi University

Lusardi, A.\& Olivia,S.M.(2007). Baby boomer retirement security: The roles of planning, financial literacy, and housing wealth. Journal of Monetary Economics, 54(1), 205-224.

Mahfudh, A. M. (2014). Financial literacy and investment decisions of UAE investors.pdf.

Merika, A. A. (2008). Economic Factors and Individual Investor Behaviour. Journal of Applied Business, 20 (4), $93-98$.

Müller S. \& Weber, M. (2010). Financial Literacy and Mutual Fund Investments: Who Buys Actively Managed Funds? Schmalenbach Business Review 62(2), 126-153.

Nabutola, W. (2004). Affordable housing: Some experiences from Kenya. FIG Working Week: Athens, Greece.

Musundi, K. M. (2014). The effects of financial literacy on personal investment decisions in real estate in Nairobi County.

Narula, S. (2015). Financial Literacy and Personal Investment Decisions of Retail Investors in Delhi, 4(1), 33-42.

OECD (2013). Financial Literacy Framework. In PISA 2012 Assessment and Analytical Framework: Mathematics, Reading, Science, Problem Solving and Financial Literacy. Paris: OECD Publishing. 
Owusu, E. N. (2015). Assessing the Level of Financial Literacy Among Teachers a Case Study of Sekyere East District of Ashanti Region of Ghana By Owusu, Eric Nkrumah (B.Com, Ca). Kwame Nkrumah University of Science and Technology.

Rooij, V, Maarten \& Lusardi, Annamaria \& Alessie, Rob, (2011). Financial literacy and stock market participation," Journal of Financial Economics, Elsevier, vol. 101(2), pages 449-472.

Sabri, N. A. A. (2016). The Relationship between the Level of Financial Literacy and Investment DecisionMaking Millennials in Malaysia. Taylor's Business Review, 6(August), 39-47.

N. A. Shaari, N. A. Hasan, Ramesh Kumar Moona Haji Mohamed \& Mior Ahmad Jafri Md Sabri, Financial Literacy: A study among the university students. Interdisciplinary Journal of Contemporary Research in Business, 5(2), 279-299.

Thilakam, C. (2012). The 2012 International Conference on Business and Management, 6-7 September 2012, Phuket-Thiland. UK FCA (2015)

Vasantbhai,Sakaria, andSima,Financial Literacy among Retired Persons: A case study of Rajkot City. Indian Journal of Applied Research, 3(4), 2013.

Von Gaudecker, Hans-Martin, (2011). How does household portfolio diversification vary with financial sophistication and advice?," MEA discussion paper series 11238, Munich Center for the Economics of Aging (MEA) at the Max Planck Institute for Social Law and Social Policy.

Wagner, J., \& Wagner, J. F. (2015). An analysis of the effects of financial education on financial literacy and financial behaviors.

Weinstein E.L. (2014). The Canadian Money State of Mind Risk Survey: Investor Risk, Behaviour \& Beliefs. Taylor's Business Review, 6(August), 39-47

\section{Notes}

Table 1: Factors that influence traders in their decision making

\begin{tabular}{|c|c|c|c|c|c|c|}
\hline STATEMENT & SD & D & $\mathbf{N}$ & $\mathbf{A}$ & $\mathbf{S A}$ & Mean \\
\hline To minimizing risk & $\begin{array}{l}13 \\
(8.7 \%)\end{array}$ & $0 \quad(0 \%)$ & $\begin{array}{l}37 \\
(24.7 \%)\end{array}$ & $\begin{array}{l}64 \\
(42.7 \%)\end{array}$ & $\begin{array}{l}36 \\
(24.0 \%)\end{array}$ & 3.73 \\
\hline $\begin{array}{l}\text { Expected losses in other local } \\
\text { investments }\end{array}$ & $\begin{array}{l}26 \\
(17.3 \%)\end{array}$ & $\begin{array}{l}64 \\
(42.7 \%)\end{array}$ & $0 \quad(0 \%)$ & $\begin{array}{l}25 \\
(16.7 \%)\end{array}$ & $\begin{array}{l}35 \\
(23.3 \%)\end{array}$ & 2.86 \\
\hline Ease of obtaining loans & $\begin{array}{l}28 \\
(18.7 \%)\end{array}$ & $13(8.7 \%)$ & $\begin{array}{l}38 \\
(25.3 \%)\end{array}$ & $\begin{array}{l}36 \\
(24.0 \%)\end{array}$ & $\begin{array}{l}35 \\
(23.3 \%)\end{array}$ & 3.25 \\
\hline Expected dividends & $\begin{array}{l}26 \\
(17.3 \%)\end{array}$ & $30(20 \%)$ & $12(8.0 \%)$ & $\begin{array}{l}32 \\
(21.3 \%)\end{array}$ & $\begin{array}{l}50 \\
(33.3 \%)\end{array}$ & 3.33 \\
\hline Diversification purpose & $15(10 \%)$ & $33(22 \%)$ & $\begin{array}{l}26 \\
(17.3 \%)\end{array}$ & $\begin{array}{l}29 \\
(19.3 \%)\end{array}$ & $\begin{array}{l}47 \\
(31.3 \%)\end{array}$ & 3.40 \\
\hline \multicolumn{7}{|l|}{ Personal Financial Needs } \\
\hline $\begin{array}{l}\text { Financial advisors and analysts' } \\
\text { recommendation }\end{array}$ & $15(10 \%)$ & $\begin{array}{l}35 \\
(23.3 \%)\end{array}$ & $\begin{array}{l}26 \\
(17.3 \%)\end{array}$ & $27(18 \%)$ & $\begin{array}{l}47 \\
(31.3 \%)\end{array}$ & 3.37 \\
\hline Opinions of the business partner & $15(10 \%)$ & $48(32 \%)$ & $13(8.7 \%)$ & $39(26 \%)$ & $\begin{array}{l}35 \\
(23.3 \%)\end{array}$ & 3.21 \\
\hline Friend recommendations & $13(8.7 \%)$ & $0 \quad(0 \%)$ & $\begin{array}{l}37 \\
(24.7 \%)\end{array}$ & $\begin{array}{l}64 \\
(42.7 \%)\end{array}$ & $\begin{array}{l}36 \\
(24.0 \%)\end{array}$ & 3.73 \\
\hline Family member opinions & $\begin{array}{l}26 \\
(17.3 \%)\end{array}$ & $\begin{array}{l}64 \\
(42.7 \%)\end{array}$ & $0 \quad(0 \%)$ & $\begin{array}{l}25 \\
(16.7 \%)\end{array}$ & $\begin{array}{l}35 \\
(23.3 \%)\end{array}$ & 2.86 \\
\hline \multicolumn{7}{|l|}{ Advocate Information } \\
\hline Condition of financial information & $15(10 \%)$ & $33(22 \%)$ & $\begin{array}{l}26 \\
(17.3 \%)\end{array}$ & $\begin{array}{l}29 \\
(19.3 \%)\end{array}$ & $\begin{array}{l}47 \\
(31.3 \%)\end{array}$ & 3.40 \\
\hline Past performance of the firm & $15(10 \%)$ & $\begin{array}{l}35 \\
(23.3 \%)\end{array}$ & $\begin{array}{l}26 \\
(17.3 \%)\end{array}$ & $27(18 \%)$ & $\begin{array}{l}47 \\
(31.3 \%)\end{array}$ & 3.37 \\
\hline Expected performance of the firm & $15(10 \%)$ & $48(32 \%)$ & $13(8.7 \%)$ & $39(26 \%)$ & $\begin{array}{l}35 \\
(23.3 \%)\end{array}$ & 3.21 \\
\hline
\end{tabular}

\begin{tabular}{|c|c|}
\hline Key: & SD $=$ Strongly Disagree $\quad \mathbf{D}=$ Disagree \\
\hline
\end{tabular}

Table 2: Descriptive Table

\begin{tabular}{llll}
\hline & $\mathbf{N}$ & Mean & Std. Deviation \\
\hline Financial literacy & 1050 & 2.99 & 1.298 \\
Investment decisions & 1800 & 3.31 & 1.105 \\
\hline
\end{tabular}

(Source: Field Data, 2018) 
Table 3 Model Summary of the Regression

\begin{tabular}{lllll}
\hline \hline Model & R & R Square & Adjusted R Square & Std. Error \\
\hline \hline 1 & 0.620 & .385 & .384 & 0.869 \\
\hline \hline
\end{tabular}

(Source: Field Data, 2018)

Table 4: ANOVA Statistics

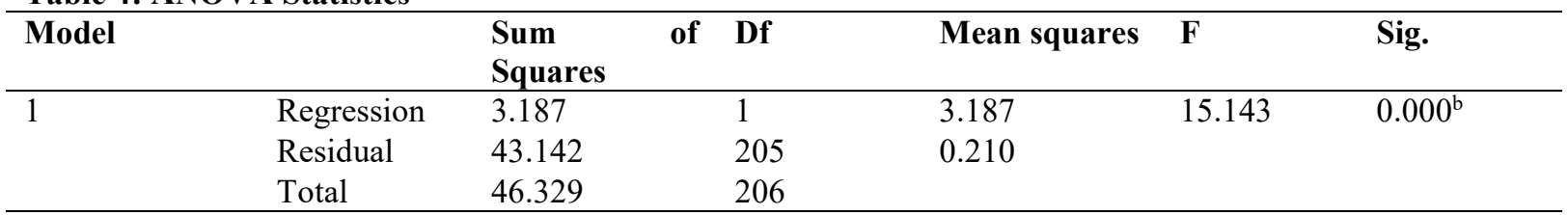

a. Dependent Variable: Investment decision

b. Predictors: (Constant), Financial literacy

Source: Field Data, 2018. 